\title{
The Copyists and their Texts. The Morisco Translations of the Qur'ān in the Tomás Navarro Tomás Library (CSIC, Madrid) ${ }^{1}$
}

\author{
Los copistas y sus textos. Las traducciones moriscas del \\ Corán en la Biblioteca Tomás Navarro Tomás (CSIC, Madrid)
}

\author{
Nuria Martínez-de-Castilla-Muñoz \\ Universidad Complutense de Madrid, España \\ Warburg Institute, Reino Unido
}

The Tomás Navarro Tomás library (CSIC, Madrid) holds thirty seven manuscripts of the Qur'ān and of tafsìr literature, copied by Mudejars and Moriscos; eleven of them are translations into Aljamía. They had been hidden in a house of the Almonacid de la Sierra village (Aragon) with no more than 1.600 inhabitants in the $16^{\text {th }}$ century. Through a careful analysis of these translations, we can state that, in spite of one exception, they exhibit a strong link between themselves as far as the copyists, the ornamentation, the paper or the textual kinship. These similarities enable us to surmise that they were all produced within a very short period, in the same area (probably in Almonacid de la Sierra itself), by a small group of copyists working with common textual sources. New hypotheses about the production and transmission of books in this area can thus be put forward.

Palabras clave: Qur'ān; Aljamia; Arabic Manuscripts; Almonacid de la Sierra; 16th Century Spain; Spanish Translations; Mudejars and Moriscos.
Escondidas en una casa del pueblo de Almonacid de la Sierra (Aragón), de no más de 1600 habitantes, se nos han conservado treinta y siete copias del Corán y del tafsì $r$, copiadas por mudéjares y moriscos siendo once de ellas traducciones a la aljamía. Hoy se encuentran en la biblioteca Tomás Navarro Tomás (CSIC, Madrid). A través de un atento estudio de estas traducciones, podemos afirmar que con la excepción de una, todas ofrecen un fuerte vínculo entre ellas: copistas, decoración, papel o parentesco textual. Estas similitudes nos permiten plantear que todas ellas se realizaron en un muy breve lapso de tiempo, en una misma zona (probablemente en el propio Almonacid de la Sierra), y que se llevaron a cabo por un pequeño grupo de copistas, que trabajaba con referentes textuales comunes. Esto permite plantear nuevas hipótesis sobre la producción y transmisión de libros en esta zona.

Key words: Corán; aljamía; manuscritos árabes; Almonacid de la Sierra; España siglo XVI; traducciones al español; mudéjares y moriscos.

${ }^{1}$ This essay has been written in the framework of the project Corana. Production and transmission of the Qur'ān in the Western Islamic World, which I lead, funded by the Spanish Ministry of Research (FFI2012-32294). I would like to thank Maribel Fierro and François Déroche for their relevant suggestions about this essay, and the librarians of the TNT for their patience and support, especially Miguel Fernández and Marifé Piquero. 
In 1606, someone saying that he knew Arabic and Spanish made somewhere in Aragon a singular copy of the Qur'ān: a complete translation of the Sacred Book in a variety of Castilian (Aljamia) in Latin letters. ${ }^{2}$ If we look at the end of the first quarter of this Quranic translation, the skills of the copyist in both Latin and Arabic scripts are obvious. Always in Spanish, he writes first in Latin script, then turns to Arabic for the next line:

Aquí se acaba el primer quarto del Alcorán onrado. No ay meter en ello duda ninguna porque está escrito en letra de cristianos, que el que lo sacó, lo copió de otro Alcorán que estaba en su propia lengua de arábigo y declarado palabra por palabra al vocablo. Y copió solamente el romance d'él para su estudio que tenía en el arábigo, y por cuanto él lo tenía prestado de una onrada gente para copiarlo en tiempo asignado; y era corto. Y porque si quisiese Allah darle gracia de cumplir con su promesa de volvérselo en dicha asignación, por tanto lo escribió en letra de cristianos. Pero haze verdad el escribano que está rectamente copiado como lo halló i que él sabe la letra de los cristianos y de los muçlimes y parte del arábigo, y que se atrevió para puxar cabo delante en su estudio como está dicho, por la brevedad que tenía consignada con quien se lo prestó. Y su letra, la de los cristianos, era la que más se atrevió para dicha ocasión. ${ }^{3}$

The manuscript is the most famous Morisco Qur'ān, known as the Qur'ân of Toledo, because it is kept in the Castilla-La Mancha library, in Toledo. ${ }^{4}$ Although the two alphabets are used simultaneously in the colophons, ${ }^{5}$ most of the volume is written in Latin script because the copy-

${ }^{2}$ For more information about the history of this manuscript and its copyist, see the preliminary study, as well as the edition of López-Morillas, Corán de Toledo. Ed. y estudio del manuscrito 235 de la Biblioteca de Castilla-La Mancha, pp. 25-29.

3 "Aquí se acaba el primer quarto del Alcorán / onrado. N[o]-ay meter en-ello duda ninguna porque / está escrito en-letra de cristianos / que el que lo-sacó lo copió de otro Alcorán q[ue] / estaba en su-propia lengua de arábigo y de/ clarado palabra por palabra al bocablo. / Y-copió solamente el-romance d'él para / su-estudio que tenía en-el arábigo y por quanto / él lo tenía prestado de una onrada / gente para copiarlo en tiemp[o] a\#signado, $\mathrm{y} /$ era corto. Y por\#que si quisiese $\mathrm{Al}[\mathrm{la}] \mathrm{h}$ darle / gracia de cumplir con su promesa de bol/ vérselo en-dicha asignación, por tanto / lo escribió en letra de [crist]ianos. Pero hazever/ dad el-escribano que es\#tá rectamente / copiado como lo-halló i que él sabe la-letra de / los cristianos i de los muçlìmes y par/te del arábigo i que se atrevió para p[uxar] /cabo delante en-su estudio como está / dicho por la brevedad que tenía consignada / con quien se lo-prestó. I-su-letra, la-de / los cristianos, era la que más se-atrebió pa[ra] // dicha ocasión [...] (Biblioteca Pública de Castilla-La Mancha, Toledo, Ms. 235 (henceforth T235), f. $81 \mathrm{v}-82 \mathrm{r})$.

${ }^{4}$ López-Morillas, Corán de Toledo.

${ }^{5}$ At the end of each of the four parts, a colophon, either in Castilian and/or Arabic, gives information about the transcription process. For its transliteration, see López-Morillas, Corán de Toledo, pp. 21-23. 
ist could write faster and more easily than when he turned to Arabic ("por cuanto él lo tenía prestado de una onrada gente para copiarlo en tiempo asignado; y era corto"). His preference may also be the consequence of his poor knowledge of Arabic, which he quite frankly admits himself ("[el escribano] sabe la letra de los cristianos y de los muçlimes y parte del arábigo"). On the other hand, the texts tells that the copyist transcribed the translation from a bilingual codex, the texts of both the Arabic and Castilian versions being probably written in Arabic script, similar in this respect to the other Morisco translations of the Qur'ān which have been preserved" ("lo copió de otro Alcorán que estaba en su propia lengua de arábigo y declarado palabra por palabra al vocablo"). If this hypothesis is correct, the copyist was merely transliterating the original Castilian in Arabic letters into Latin script. In T235, the original Arabic text has completely disappeared, a fact which induces us to cast some doubts about the wish to learn Arabic he had expressed previously ("Y copió solamente el romance d'él para su estudio que tenía en el arábigo").

This might be somehow reflected, even if this may seem a little far fetched, in the statement that the translation is a word-for-word rendition which may have been used as a kind of glossary or as a mnemotechnic reference if the user had at hand an Arabic text of the Qur'ān ("declarado palabra por palabra al vocablo"). However, when analyzing the translation, we have to admit that this is not the case and that it is by no means literally faithful to the Qur'ân text. The Spanish version shows that Quranic commentaries have been introduced in a systematic manner. That means that we are far from the word-for-word faithful translation this text is supposed to be. ${ }^{7}$

Exceptional as this translation may be, it is not unique, in the sense that various other translations produced in the frame of Morisco communities have survived. In this paper, I shall analyze the Qur'ān translations

${ }^{6}$ Beside this copy, one other Quranic manuscript offers a translation into Spanish in Latin script: Paris, BnF 447. However, this manuscript, copied in Salonica in 1569, contains the interlinear translation of some excerpts of the Qur'ān, alongside the Arabic text (see Martínez-de-Castilla, "Corán de Salónica," p. 228; and Martínez-de-Castilla, "Deux corans aljamiados de Salonique," pp. 4-5).

${ }^{7}$ In spite of these opening remarks, the inclusion of exegetical commentaries into the translation can be seen in the beginning of the manuscript since they are written in red ink. This aspect has been faithfully rendered in López-Morillas' edition by the use of colours according to the original; in the same way, the use of the tafsir in this manuscript is amply indicated. 
which are part of the Almonacid de la Sierra collection (Aragon) from a comprehensive point of view: what are their similarities and their differences with regard to their material features, their decorative components and their textual aspects, taking into account, as far as the last point is concerned, both the contents (which Quranic fragments do they transmit) and the relationship between those translations from a philological/ecdotical point of view. The aim is to identify the place and date of copy of those texts; to explain the translation and/or copy process itself through the identification of the copyists involved in this task - even if they remain anonymous- and the analysis of the texts used in order to carry out the translations; and the various uses of each volume. ${ }^{8}$ For that purpose, I shall rely on the Quranic translations kept in the Tomás Navarro Tomás library of the Spanish National Research Council (CSIC) in Madrid and originat-

${ }^{8}$ Thanks to a JAE-doc contract at the CCHS-CSIC (2008-2010), I have been able to carry out my project of cataloging the Almonacid de la Sierra manuscripts collection. Before the end of this project, the results I had then compiled about the Aljamiado manuscripts and Qur'āns in Arabic kept in the TNT library were graciously handed over upon request of the cataloging and digitization project of the Madrid and Granada CSIC manuscripts collections. Its portal $<$ http://manuscripta.bibliotecas.csic.es $>$, became accessible in 2011 . The call numbers referred to in the present paper are those which it was decided to use at this moment since the proposal to change these call numbers was rejected. However, new call numbers would have been very helpful to understand the history of the collection. Although each call number should be associated in principle with a manuscript, a few call numbers correspond actually to a box where various quires (in a few cases many of them) from different manuscripts are lumped together. Due to the fragmentary state of the collection, Julián Ribera and Miguel Asín who were heading the group of cataloguers of the then Junta para la Ampliación de Estudios collection decided probably to include them in the same box without any other reason than the size of the paper. A century later, the system which was selected and took over the previous call numbers (with the exception of the change to RESC/ instead of the old "J" letter for "Junta") entailed a difficulty for the digital catalogue. For this reason, it was decided to designate through a capital letter each of the various codicological units found under the same call number -be it a factitious codex, compiled in 15th or 16th centuries, or a box with fragments from various manuscripts, put together in 20th century. RESC/39E designates for instance the fifth codicological unit in the box number 39- as I found it when I prepared the catalogue of these manuscripts. As for the Arabic numerals after a dot, as in RESC/3.1, they refer to the order occupied by the translation of the Qur'ān within the miscellany where it is found. RESC/3.1 means for instance that the translation is the first component of the manuscript (a miscellany) number 3. Conversely, in the cases which concern us here, if there is only a numeral after RESC, like RESC/51, it means that we are dealing with a unitary manuscript. (More information about these features in Martínez-de-Castilla, "Manuscritos musulmanes y facticios del Aragón del siglo XVI"). The corrected and completed data about Mudejar and Morisco Quranic manuscripts kept in the Tomás Navarro Tomás library are available in Martínezde-Castilla, "Qur'ānic Manuscripts from Late Muslim Spain. The Collection of Almonacid de la Sierra." 
ing from the Almonacid de la Sierra trove at the beginning of the 19th century: as a whole, it is the most important testimony about the Arabic and Aljamiado manuscripts a Morisco community had at its disposal.

In spite of the importance of this collection, the studies published so far focus on specific topics and many scholars tend to favour the transliteration of the texts contained in the manuscripts. ${ }^{9}$ López-Morillas pushed much further the research on the translations of the Qur'ān, analyzing twenty-five manuscripts from the Mudejar and Morisco periods containing material translating or paraphrasing the Arabic Qur'ān and kept in this and other libraries; these studies are especially important as they help us to approach the world of the Qur'ān within Mudejar and Morisco communities. ${ }^{10}$ However, in this analysis so important in many aspects, López-Morillas tries to establish links between the manuscripts which have been preserved, but fails to take into account the textual identity of the copies, closely related to the uses and patrons of the latter, and the material losses impacting the codex once it had been transcribed. ${ }^{11}$

\footnotetext{
${ }^{9}$ See the bibliography at the end of this paper, especially the transcriptions made by Vernet and his students.

${ }^{10}$ Her numerous publications related to this topic show the importance of her contribution to the study of the Qur'ān in its Aljamiado translation; see for instance: López-Morillas, The Qur'ān in Sixteenth-Century Spain: Six Morisco Versions of Sūrat al-Nāzi 'āt; López-Morillas, “"Trilingual' Marginal Notes (Arabic, Aljamiado and Spanish) in a Morisco Manuscript from Toledo"; López-Morillas, "Lost and Found? Yça of Segovia and the Qur'ān Among the Mudejars and Moriscos"; López-Morillas, "La autoría del manuscrito coránico morisco T235"; López-Morillas, "El Corán romanceado: la traducción contenida en el manuscrito T235" [=Homenaje a L. P. Harvey]; López-Morillas, "The Genealogy of the Spanish Qur'ān"; López-Morillas, Corán de Toledo.

${ }^{11}$ It seems necessary to develop a larger investigation based on a comprehensive study of the production and circulation of the Quranic copies among the various Mudejar and Morisco communities, in order to get a clearer view of the Qur'ān translations circulation among these communities, although this would be the subject of another study. However, it should not be forgotten that the Aljamiado translations of the Qur'ān do not even account for a third of the total of the Quranic texts which have been preserved, as comes out clearly from the Almonacid de la Sierra collection with 37 fragmentary copies of the Qur'ān, from which only 11 are translations. See Martínez-de-Castilla, "Qur'ānic Manuscripts from Late Muslim Spain.” We would have to take into account the other Quranic copies probably produced in Aragon (cf. the different library catalogues, especially: Álvaro Galmés de Fuentes, Los manuscritos aljamiado-moriscos de la Biblioteca de la Real Academia de la Historia (legado Pascual de Gayangos); Guillén Robles, Catálogo de los manuscritos árabes existentes en la Biblioteca Nacional de Madrid; or Martínez-de-Castilla, Les manuscrits mudejars et morisques en France), as well as the information found in the Inquisition archives, for instance the data compiled by Jacqueline Fournel-Guérin about Aragon (in "Le livre et la civilisation écrite dans la communauté morisque aragonaise (1540-1620)").
} 
A total of eight such copies in Aljamia as well as three glossaries have been preserved in the Tomás Navarro Tomás library as it is known today. ${ }^{12}$ On the basis of a codicological analysis, we can state that all date back to the $16^{\text {th }}$ century. Only one manuscript has raised a discussion about its date of composition: RESC/3. Wiegers, following the edition by Kontzy, had already indicated that the manuscript "should be dated in 1586 or later, a date mentioned in the text on f. $222 \mathrm{v} . "{ }^{13}$ But Montaner suggested that $\mathrm{RESC} / 3$ was transcribed at the beginning of the 17th century: "la presencia en los hallazgos de varios textos de principios del siglo XVII (mss. [...] Junta III." 14 In any case, RESC/3 is a miscellany written by various hands, apparently at the same time (or within a rather short time span). When looking at the paper, which remains the same throughout the volume, we find a watermark with a "a musketeer or a pilgrim." A similar watermark has been found in papers from Ejea de los Caballeros ${ }^{15}$ and from Ateca and Daroca and dated between 1547 and 1568: the letters that can be seen below and the cross on top of the circle do not coincide with the watermark found in RESC/3, but the figure itself matches that of the Aljamiado manuscript. ${ }^{16}$ A similar watermark can be observed in the Digital Publication of the "Piccard" Collection of Watermarks: n. 21423-21430. ${ }^{17}$ In this case, we are dealing with an Italian paper dated between 1554 and 1577, dates which are quite close to the evidence collected in Robles. In O. Valls i Subirà ${ }^{18}$ this shape is only found in 16th century papers, each time more distorted as the century goes on (nothing similar is recorded in the 17th century). Moreover, the dates suggested by the observation of the paper match those indicated in the manuscript itself: "año de 1587" (RESC/3, f. 134r).

In this collection of Quranic copies kept in the same place since probably the beginning of the $17^{\text {th }}$ century, the attention is drawn by the large

${ }^{12}$ For a complete description of these copies, see Martínez-de-Castilla, "Qur'ānic Manuscripts from Late Muslim Spain,” pp. 104-133.

${ }^{13}$ Wiegers, Islamic Literature in Spanish and Aljamiado. Yça de Segovia (fl. 1450), His Antecedents and Successors, p. 226.

${ }^{14}$ Montaner, "El auge de la literatura aljamiada en Aragón," p. 54.

${ }^{15}$ Robles Salgado (coord.), Filigranas en la provincia de Zaragoza, pp. 89-90.

${ }^{16}$ See Robles Salgado (coord.), Indice de filigranas en la provincia de Zaragoza II, $\mathrm{p}$. 22 and 50 .

${ }^{17}$ Digital Publication of the "Piccard" Collection of Watermarks.

${ }^{18}$ Valls i Subirà, La historia del papel en España, vol. II, pp. 233-235. 
amount of translations of the Muslim sacred text produced at a time when the profession of any other faith than Catholicism was prohibited -at least theoretically- in the Spanish kingdoms. One has to remember that in 1502 (or 1526, depending on the kingdom) all Muslims living in the Iberian Peninsula were compelled to convert to Catholicism or to leave the territories; some years later, Arabic was also banned: among many other interdictions which were enforced during the $16^{\text {th }}$ century, writing and speaking Arabic as well as owning books in that language became liable to prosecution by the Inquisition.

In spite of this situation, the copy of the Qur'ān -both in Arabic and in commented translation- was still carried out in the Almonacid de la Sierra area until at least the end of the $16^{\text {th }}$ century in various typologies: ${ }^{19} \mathrm{com}-$ plete copies, ${ }^{20}$ portions of the text, excerpts or glossaries. Although each of the mentioned groups are attested among the 37 copies of the Qur'ān kept in the TNT library, no complete translation has been preserved (perhaps there never was one). Actually, in all the Morisco manuscript production, the Qur'ân of Toledo (T235) is the only witness we have of a complete translation of the Sacred text of Islam; in this single volume copy, the text is also divided into four parts. This copy is not only exceptional for the translation, but also for the fact that the Castilian version comes without the Arabic original and is moreover written in Latin letters. Conversely, all the copies of the Quranic translations kept in the Tomás Navarro Tomás library they are all bilingual, in Arabic script; that is, both Arabic and Aljamiado text are present. The distribution of both languages, although written in the same script and distinguished from each other through the use of a thicker or thinner qalam, varies according to the manuscripts: in this way, the text in the two languages appears in a disposition in paragraphs, in interlinear distribution or in two columns.

From the point of view of the nature of the texts, the translations of the Qur'ān kept in the TNT can be assembled into three clusters: Commentary-translation of portions (quarters) of the Qur'ān; Excerpts; and Glossaries, closely related to I.

${ }^{19}$ Cf. Martínez-de-Castilla, "Qur'ānic Manuscripts from Late Muslim Spain.”

${ }^{20}$ Martínez-de-Castilla, "'Hacer libros no tiene fin'. Los moriscos aragoneses y su patrimonio manuscrito," p. 754. 


\section{Commentary-translation of the first and fourth quarters of the Qur'ān II. III. Glossaries}

Four manuscripts kept in the TNT library contain a fragmentary copy of the translation of one of the quarters of the Qur'ān, two of the first one, $\mathrm{RESC} / 51^{21}$ and $\mathrm{RESC} / 52.1^{22}$, and two of the fourth one, RESC/18 $8^{23}$ and RESC/47. ${ }^{24}$ They all exhibit a translation alternating with the Arabic text, the latter being shorter than the translation. This is due to the fact that the aljamiado text is no a word-for-word translation, but includes many commentaries or tafäsìr of the Quranic text.

The original scheme behind these bilingual copies seems to have been an interlinear distribution of the translation. Under these conditions, the copy of the Arabic text and of its commentary-translation was not easy to organize, above all if the Arabic text was transcribed first, the translation being inserted during a second stage. This is what we find on many folios of RESC/18: the copyist wrote first the Arabic text, without adequately foreseeing the space which would have been required when he would have to insert the translation and the commentary. For this reason, when he had to transcribe the Aljamiado text, he was forced to avail himself of any empty space available to add his commentaries (see fig. 1).

The Arabic text of the Qur'ān of RESC/52.1 is not complete whereas the translation of the commentary appears as the main text. For this reason, we may find various folios without any fragment in Arabic and only the commentaries in Aljamia (v. gr. RESC/52.1, f. 12r-v). As the Arabic text is not complete, a comparison between the reference text and the translation of the commentary is problematic.

${ }^{21}$ Transcribed by Losada, Estudios sobre coranes aljamiados.

${ }^{22}$ The manuscript is dealt with here for the first time after the summary reference to this work in Ribera and Asín's catalogue: “(Fol. 1-243). Otro ejemplar de la obra que contiene el ms. num. LI; más extenso, pero también incompleto. Muy deteriorado por el fuego, sobre todo los últimos cuadernos, que están casi por completo destruidos" (Ribera and Asín (dirs.), Manuscritos árabes y aljamiados de la Biblioteca de la Junta, p. 191); I have seen no reference to it, not even in the comprehensive study by López-Morillas, "The Genealogy of the Spanish Qur'ān," or in its book El Corán de Toledo, nor in the Ph.D. thesis by Teresa Losada (Estudios) on Ibn Abī Zamanīn's tafsīr found in RESC/51.

${ }^{23}$ Transcribed by Vernet and López-Lillo, "Un manuscrito morisco del Corán."

${ }^{24}$ Hermosilla Llisterri, "Una versión aljamiada del Corán 58, 1-3"; Hermosilla Llisterri, "Una versión aljamiada del Corán 58, 1-3"; and Hermosilla Llisterri, "Corán 22, 52 en el tafsìr de Yahyà b. Salām." 


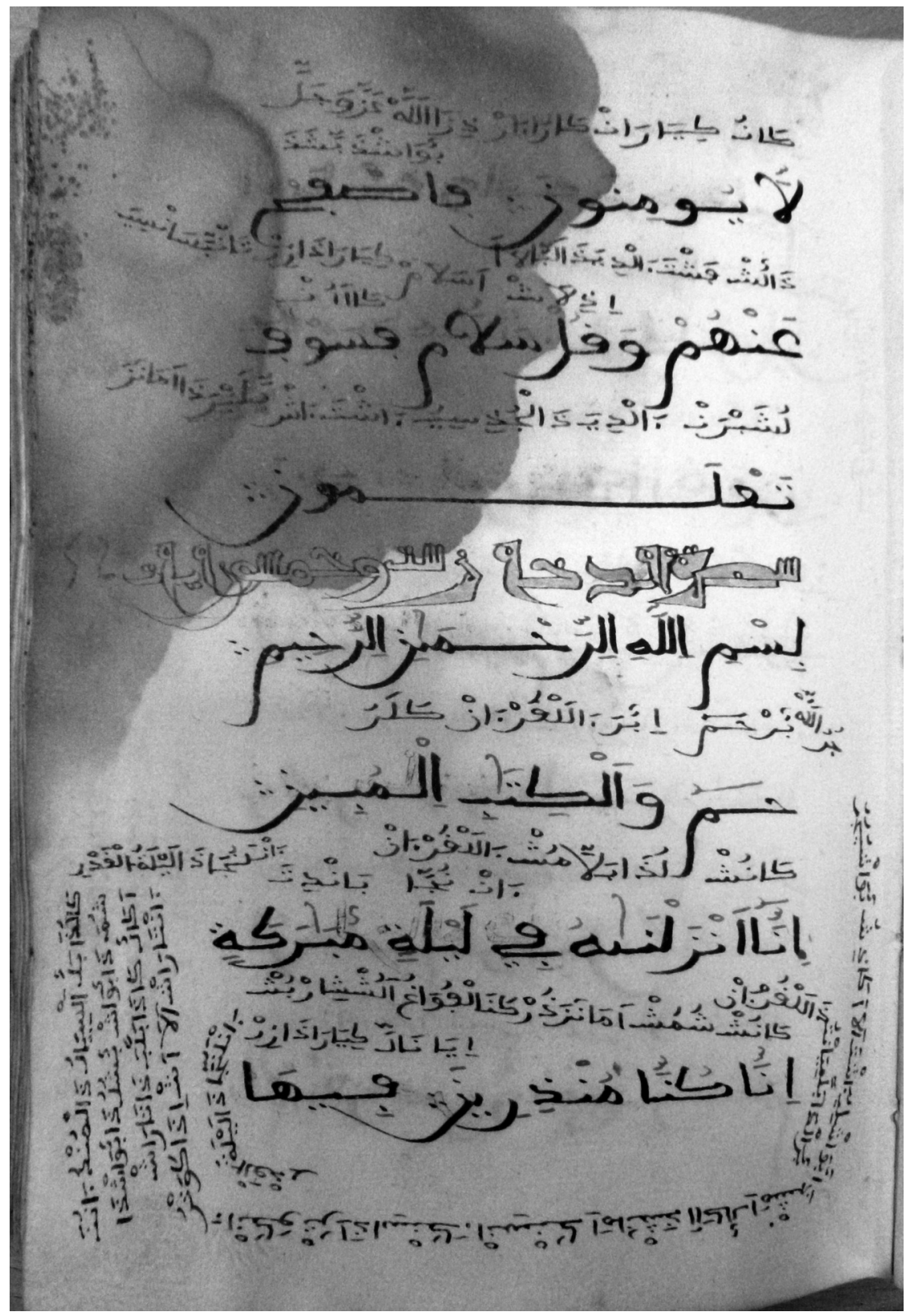

Fig. 1. RESC/18, 52r.

CCSIC, Centro de Ciencias Humanas y Sociales, Biblioteca Tomás Navarro Tomás Al-Qantara XXXV 2, 2014, pp. 493-525 ISSN 0211-3589 doi: 10.3989/alqantara.2014.017 
$\mathrm{RESC} / 47$ as well as RESC/51 follow the same layout pattern, exhibiting a strange distribution of white spaces in the middle of the lines, without any apparent reason; it is hardly thinkable that they were left for the translation since in a few cases, for instance RESC/47, f. 58r, or RESC/51, f. $149 \mathrm{v}$ (cf. fig. 2 and 3), the white space is found in the middle of a phrase in Arabic. In addition to the similarity in the mise-en-page, both copies seem to have been transcribed by the same hand or, at least, by two copyists who were using the same script.

As far as the contents are concerned, two of these manuscripts contain the tafsir of the first quarter of the Qur'ān (corresponding to the first six suras or chapters), the remaining two containing the last quarter (from süra 38 to the end). The division of the Quranic copies themselves (in Arabic only or in Aljamia translation) as well as of the tafäsì into four parts correspond to a widespread Western Islamic tradition, found either in single volume copies or in four volumes sets. In the present case, the fact to have four independent volumes, each of them corresponding to one of these four parts of the Qur'ān of equal length, is probably due to the wish to have more user-friendly books that the copy and translation of these tafäsìr. ${ }^{25}$ For this reason, stating that

la división en cuatro secciones que encontramos en el ms. T235 podría ser, pues, un elemento introducido por Yça [who explained this tradition to Juan de Segovia] y conservado en copias intermedias (hoy desconocidas) hasta que reapareció en $1606^{26}$

does not fit neither with a well-known situation in other parts of the Western Islamic world, nor with Morisco usage.

RESC/51 contains the commented translation of the first part of the Qur'ān: "aunque muchas traducciones aljamiadas del Corán contienen interpolaciones sacadas de obras árabes, es esta [RESC/51] la única obra llamada explícitamente 'tafsīr' que poseemos en versión aljamiada." ${ }^{27}$ However, in another manuscript in the TNT collection, RESC/47, the

${ }^{25}$ With very few studies on this topic available, it is necessary to look at the catalogues of Arabic manuscripts collections like that of the Bibliothèque nationale de France (Déroche, Catalogue des manuscrits arabes II. Manuscrits musulmans, passim) or to search directly in the collections in order to realize that the sets of four volumes with the Quranic text were common and involved a widespread use; it was also known among the Moriscos in a late development of Islam in the Iberian peninsula.

${ }^{26}$ López-Morillas, Corán de Toledo, p. 40.

${ }^{27}$ López-Morillas, Corán de Toledo, p. 146. 


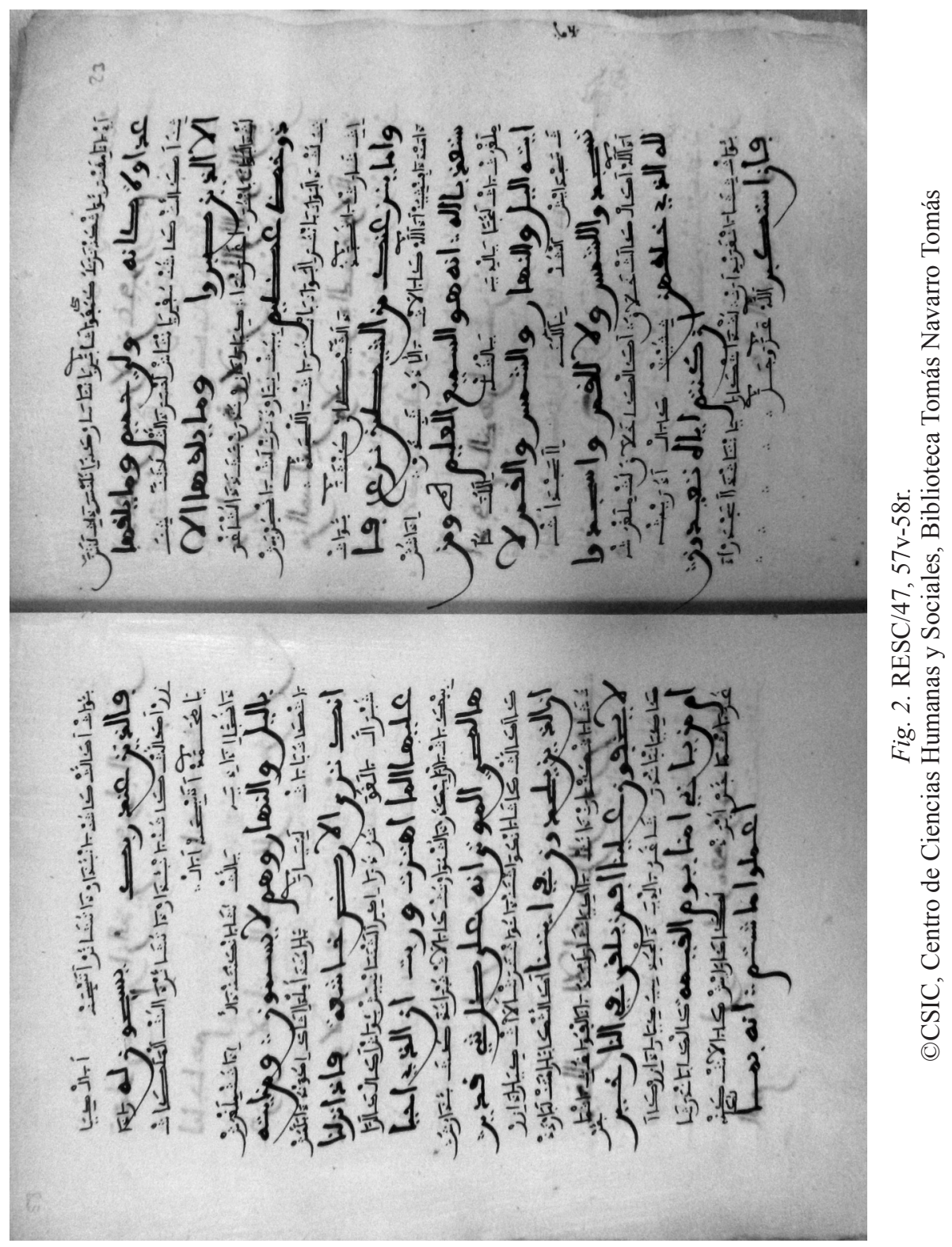




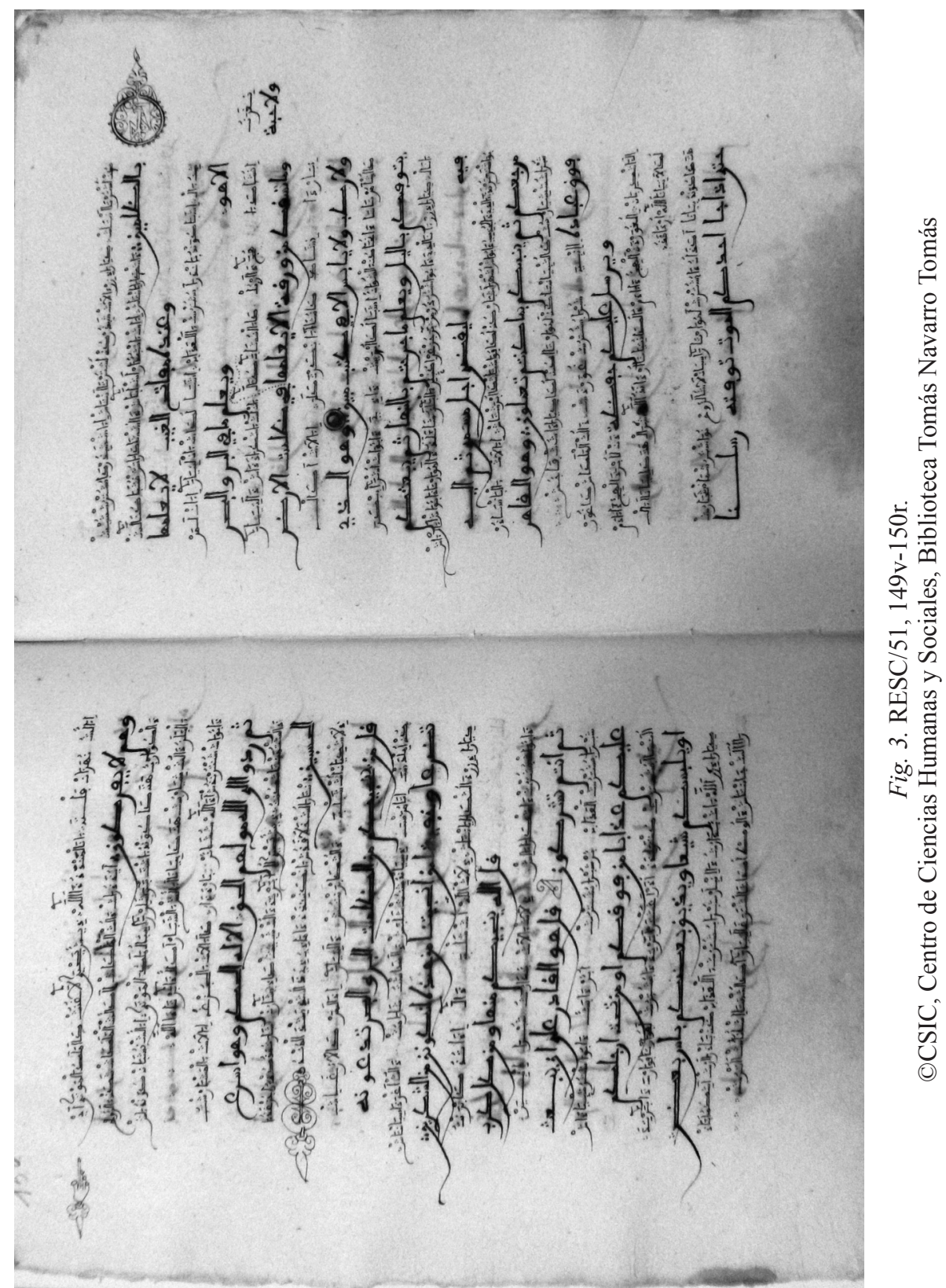


"comentario es [también] mucho más extenso que el texto coránico."28 In this case the copy is a tafsir of the fourth part, which has not drawn the same attention as in RESC/51. Both copies contain commented translations of the Qur'ān and share codicological features. As we have seen, they are thus graphically as well as aesthetically quite close to each other; these textual and codicological similarities induce us to conceive a kinship between these copies. However, we can state that RESC/47 and RESC/51 are not part of the same set. From a codicological point of view, there are many important differences: their size: 250x180mm (textblock 177x130mm) and 292x215mm (text-block 206x131 mm) respectively and their paper are different; the number of lines/page (20 and 22) and the type of quires also differ. From a textual point of view, Hermosilla says:

Confrontando exhaustivamente el texto aljamiado del ms. XVLII con el árabe del Tafsìr de Yahyyà ibn Salām, según el ms. n. 34 de la biblioteca de al-Qarawiyyīn de Fez, hemos visto que el ms. XLVII no es la traducción de dicho Tafsìr, sino un Corán aljamiado con extensos comentarios de estructura compleja, que en conjunto sigue el Tafsìr de Yahyà, con absoluta literalidad en algunos pasajes y menor o nula en otros, donde es sustituido por materiales de diversa procedencia [...]. El ms XLVII sigue, en general, el Tafsìr de Yahyyà ibn Salām. ${ }^{29}$

If we keep to Hermosilla's hypotheses, we can nevertheless conclude that the way in which the Aljamiado translation of both manuscripts was handled, with regard to Ibn Abī Zamanīn's tafsìr, is not identical, RESC/51 being more faithful to the original than RESC/47. However, althougt the two manuscripts do not belong to the same set and in spite of these discrepancies, it cannot be excluded that they descend from a common original which in its turn could have been drawing from various sources and exhibited this strange layout for the text.

We have seen before that, regardless of RESC/47, the only manuscript in the extant Morisco production considered as a proper tafsī is RESC/51. Actually, RESC/51 has been thoroughly analyzed, having even been the subject of a PhD Thesis. ${ }^{30}$ The finding of RESC/52, never examined until now, casts a doubt on this matter: why was the copy RESC/52 never taken into consideration by researchers who studied the Morisco Quranic copies

${ }^{28}$ López-Morillas, Corán de Toledo, p. 146.

${ }^{29}$ Hermosilla, "Una versión aljamiada de Corán 89, 6-8," pp. 34-35 and 60.

${ }^{30}$ Losada, Estudios sobre coranes aljamiados. 
or exegetical commentaries? It may be due to its size or to its careless layout. The tafsir found in RESC/52 is the first text of a large unbound manuscript, now divided into two volumes. It is the tafsìr by Ibn Abī Zamanin of the first quarter of the Qur'ān, and it belongs to the same textual tradition as RESC/51; the big difference between them lies in the fact that RESC/52.1 only transmits in a fragmentary way the Arabic text. ${ }^{31}$ Manuscripts RESC/51 and RESC/52.1 are thus the work of two different copyists, but belong to the same textual tradition; i.e. they were transcribed from the same model. This does not surprise us because after a study of the other manuscripts of the Almonacid collection, we know that the copyst of RESC/5 and RESC/52.1 were associated in the transcription process in various occasions. Actually, in the same miscellany manuscript (RESC/52), we find them writing on the same page a few folios after the section containing the tafsir .

These are two more examples allowing us to state with López-Morillas that "las versiones del Corán español existen dentro de un denso entramado de conexiones e influencias mutuas." ${ }^{32}$ Actually, we will see that the Qur'ān translations of manuscripts RESC/39E and RESC/58B were copies from the same original and resulted in two almost identical manuscripts; and the manuscripts RESC/51 and RESC/52.1, in spite of being two visually different products, each with a specific handling of the Arabic text, exhibit a translation which was taken without any doubt from a common original. For this reason, statements like "los manuscritos que nos han llegado se habrán nutrido de un número mucho más grande de textos anteriores, de forma que casi ninguno tendría una ascendencia clara e individual" ${ }^{\prime 3}$ should be reappraised in the light of codicological and ecdotical studies.

These three closely interrelated translations of the tafsir, two of the first quarter and one of the fourth, induce us to emphasize the fact that there might have been other volumes containing the commentary of the other parts of the tafsir.

Coming back to the fourth part. Both manuscripts RESC/18 and RESC/47 contain the tafsìr of the fourth quarter of the Qur'ān, but they do not have many things in common: they were not transcribed from the

${ }^{31}$ I am currently preparing a comprehensive study of these manuscripts, including an edition of RESC/52.1.

${ }^{32}$ López-Morillas, Corán de Toledo, p. 81.

${ }^{33}$ López-Morillas, Corán de Toledo, p. 81. 
same original - we have already seen that RESC/47 includes more exegetical commentaries than those collected in Ibn Abì Zamanīn's tafsìr , while "el manuscrito 18 de la Escuela de Estudios Árabes de Madrid coincide exactamente con el Mujtașar tafsìr de Yahyà b. Salām de Ibn Abì Zamanin" "34; and they exhibit different copy procedures: the size, layout, type of paper, vocalization, coulour of inks, verse ending marks and so on are different.

On the other hand, if we take into account Hermosilla's analyses ${ }^{35}$ the $\mathrm{RESC} / 40$ glossary is in complete agreement with RESC/18 translations; and for López-Morillas: "El léxico de Junta XLVII es casi idéntico al glosario de términos coránicos en árabe y aljamiado de que consta el ms. Junta XL," although she does not specify which glossary she is referring to. ${ }^{36}$ These statements lead us to think that either both were depending on a common source, or that the copyist of RESC/18 and RESC/47 used the RESC/40 glossaries when translating the text. Another witness of the same textual tradition would be needed to reach a final conclusion on this question.

The fact that only translations of the first and fourth quarters of the Qur'ān have been preserved can lead us to put forward contradictory hypotheses. On the basis of the extant witnesses, one could think that the Morisco communities were only interested in those parts, but to this day there is not enough evidence to support this hypothesis and it is actually probable that the distribution of the text in four volume sets increased the possibility of some of them being lost over the years. If we also consider the copies of the Qur'ān from Almonacid de la Sierra in Arabic (without any translation), we see that two manuscripts contain the fourth part: RESC/3.3 and RESC/16,C.1; no copy of the first part has been preserved, but one of the third part, RESC/34, is still extant. ${ }^{37}$ The lack of complete copies or, at least, of all four parts, especially of the first one, induces us to think that although the copies were complete at the beginning, part of the material was lost at a later date.

In any case, the translations-commentaries of the parts which did survive in the Almonacid de la Sierra trove are fragmentary, especially in the case of the two tafsir manuscripts containing the fourth part, a point which

\footnotetext{
${ }^{34}$ Losada, "Estudio sobre coranes aljamiados. Resumen de la tesis doctoral," p. 11.

${ }^{35}$ Hermosilla, "Dos glosarios de Corán aljamiado," p. 118.

${ }^{36}$ López-Morillas, Corán de Toledo, p. 148.

${ }^{37}$ For more information, see Martínez-de-Castilla, "Qur'ānic Manuscripts from Late Muslim Spain."
} 
suggests that what is now missing has been lost in the course of time. This division of the tafsir into four parts is further confirmed by the glossaries of words and phrases which coincide with the commentaries dealing with the fourth part of the Qur'ān (RESC/40C, ${ }^{38}$ RESC/40D.1 and RESC/40D.2). ${ }^{39}$

Starting from the hypothesis that the parts which have been preserved are the surviving witnesses of complete copies of the Qur'ān, in Arabic as well as in commented translation, we distance ourselves from the last part of López-Morillas' conclusion that "es un hecho que no sobrevive ninguna otra versión coránica [que la de Toledo], sea en español o en aljamiado, que siquiera pretenda ser completa." 40 Although it is true that no other complete translation of the Qur'ān than T235 seems to have survived, at least some of those which have been preserved seem to have been conceived as complete translations, according to the data we have at hand.

\section{Translation of excerpts of the Qur'ān. The "Morisco Qur'ān"}

On the other hand, four copies of excerpts of the Qur'ān have been preserved, that is to say with a homogeneous selection of verses, with either an interlinear translation (RESC/3.1, RESC/25 $5^{41}$ ), or a paragraph by paragraph rendition (RESC/39E, RESC/58B.1).

As we have already seen, in the Almonacid de la Sierra collection, almost all the manuscripts are linked together in some way, with the exception of RESC/3.1, which stands apart in comparison with the rest of the production. If the manuscript was copied at the beginning of the $17^{\text {th }}$ century, as Montaner suggested, the difference would be easier to explain, but it seems probable that it was transcribed during the $16^{\text {th }}$ century. ${ }^{42}$

${ }^{38}$ Glossary with Quranic terms, probably incomplete. There are many blanks, and we cannot exclude the loss of other quires. It is a folded and sewed folio (vertical), and folded again in order to be easier to handle.

${ }^{39}$ For a description, Martínez-de-Castilla, "Qur'ānic Manuscripts from Late Muslim Spain," p. 96, pp. 113-115. For further study and the edition of the transliteration of the texts, see Hermosilla, "Dos glosarios," pp. 117-149.

${ }^{40}$ López-Morillas, Corán de Toledo, p. 12. 43-75.

${ }^{41}$ Transcribed by Vernet and Moraleda, "Un Alcorán fragmentario en aljamiado," pp.

${ }^{42}$ See p. 498 of this article. 
As in the previous group (I), the links can be of various nature: codicological and textual. The case of the excerpts RESC/39E and RESC/58B.1 is unique. They are twin copies of the same text; in this case, selections from the Qur'ān with a paragraph by paragraph translation, written by the same copyist (see fig. 4 and 5). In both cases, the production techniques are identical: dimensions of the paper sheets $(175 \times 119 \mathrm{~mm})$ and of the written surface $(119 \times 73 \mathrm{~mm})$, script, kind of paper used (Western paper with a vertical watermark), ruling, use of catchwords, and so on. The copyist is so skilled that the layout is strictly the same, to such an extent that it is almost impossible at first sight, both manuscripts being nowadays in the shape of unbound quires, to decide whether a quire is part of one manuscript or of the other one; actually, the lines begin and end with the same word in both copies. If we take into account the materials preserved from both RESC/39E and RESC/58B1, we can suggest that they are the remnants of two unbound manuscripts meant to transmit the "Morisco Qur'ān."43

As was the case with RESC/47 and RESC/51 or with RESC/39E and RESC/58B.1, the manuscripts RESC/25 and RESC/18 (see fig. 6 and 7) are also the work of the same copyist, but in this case we are dealing with two different kind of contents: the text transmitted by RESC/25 is a copy of Quranic excerpts, with an interlinear translation (I, II: 1-5, 163, 255257, 284-286; III: 1-6, 18-19 (1 ${ }^{\text {st }}$ part), 26-27; IX: 128-129; XXVI: 78-89; XXVIII: 88; XXX: 17-19; XXXIII: 40-44; XXXVI; LV; LXVII; LXXVIII-CXIV; ${ }^{44}$ whereas RESC/18 is a translation alongside the tafsìr of the fourth quarter of the Qur'ān. Unfortunately, it seems that RESC/18 was never completed and that only the part corresponding to the suras XLI to LVI has been transcribed. Although we could think that the manuscript RESC/18 is acephalous, because the fourth part should start with sura XXXVIII, such is not the case. The text starts on $\mathrm{f} .2 \mathrm{v}$, the first folio being left blank, as a preliminary leaf. However, at the end, the text breaks off in the middle of f. 190r, followed by two blank folios. As this disposition is quite unusual and matches that of incomplete codices, I am induced to think that the work was never completed.

As in the previous case, manuscripts RESC/25 and RESC/18 are closely related, from a codicological point of view. The kind of paper used

${ }^{43}$ A definition of what I term "Morisco Qur'ān" and an analysis about it, in Martínezde-Castilla, "Qur'ānic Manuscripts from Late Muslim Spain," p. 96.

${ }^{44}$ To this selection, "unas aleyas del Corán de mucha virtud" (in red ink) have been added in f. 93r-100r: II: 152-157; XVIII: 107-110; LVI: 75-96; LIX: 18-24. 


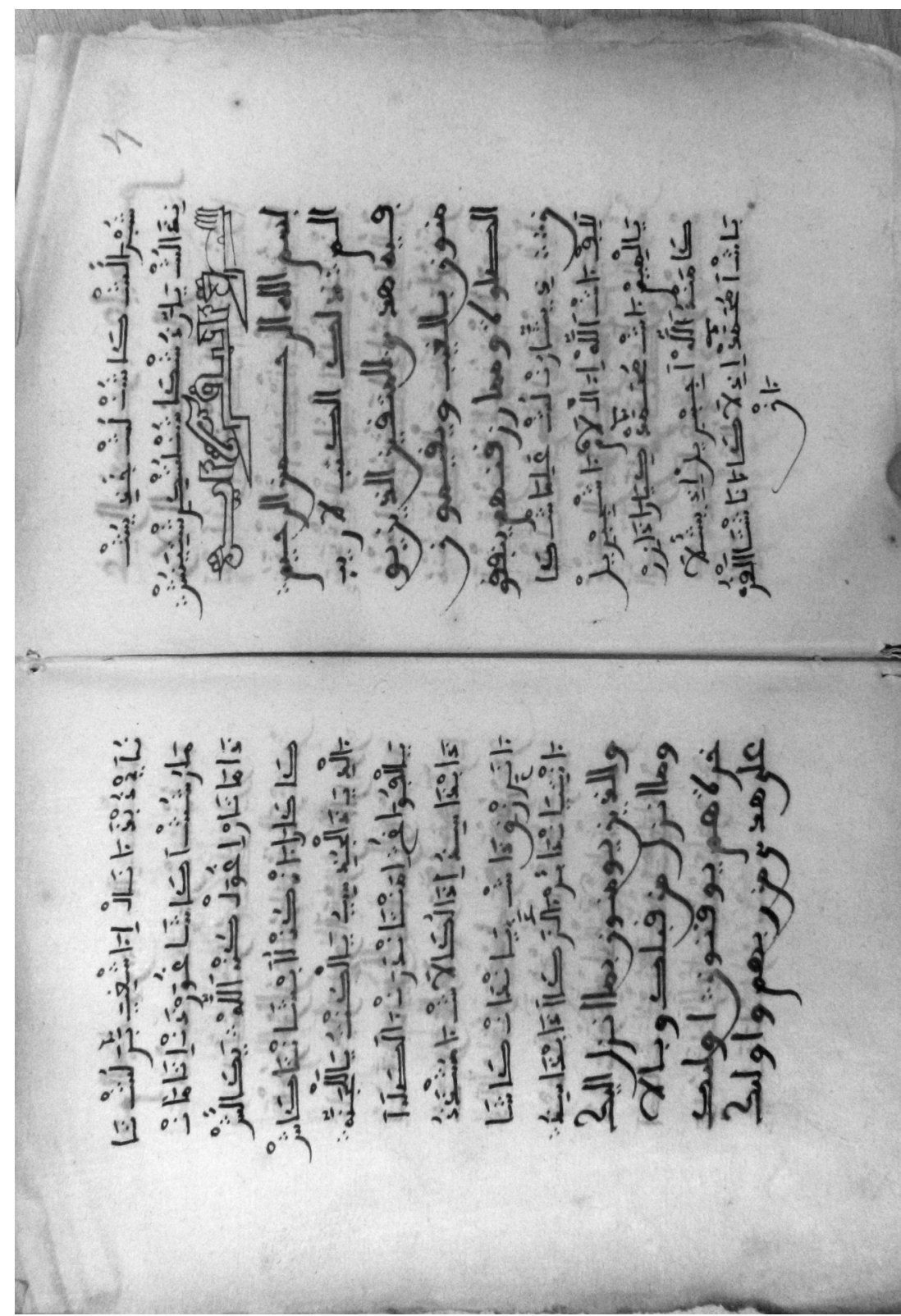

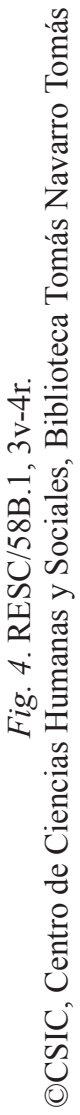




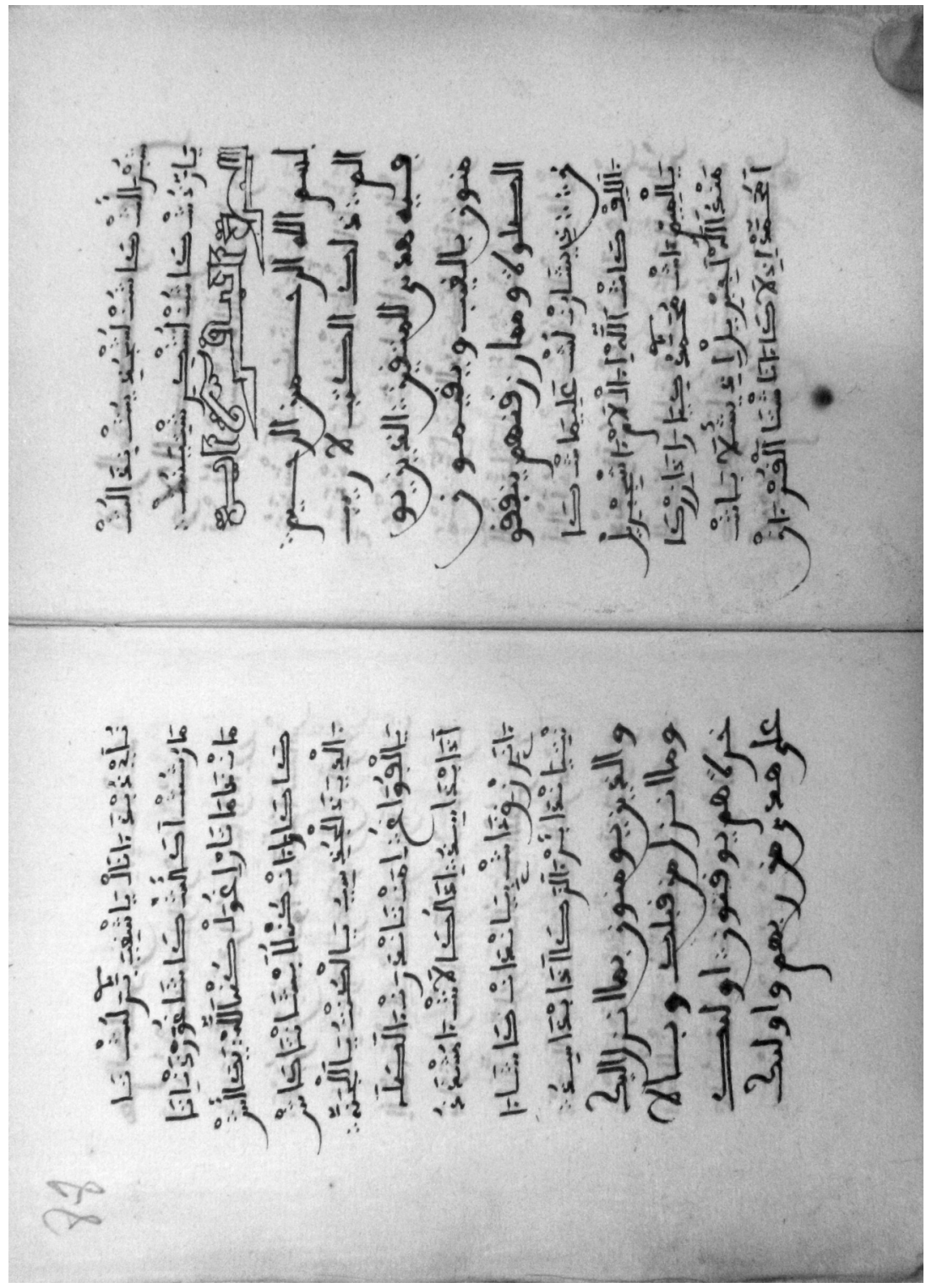

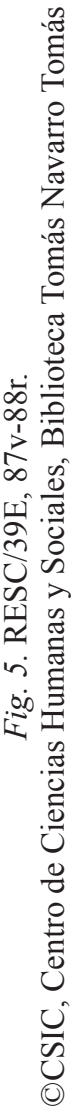


for both is the same, the dimensions of the paper sheet $(205 \times 140 \mathrm{~mm})$ and of the written surface $(151 \times 95 \mathrm{~mm})$ coincide, the ruling is identical, an interlinear presentation of the translation is found in both cases, and the layout of the Quranic text and its translation are identical, even in the number of lines per page. However, from a textual or ecdotical point of view, we cannot decide whether both texts derive from the same source or the copyist of the two codices relied on two different manuscripts when he performed the transcription. This is most unfortunate as textual elements of comparison would have been a firm starting point for the identification of the commentaries selection upon which the various texts were relying -if such was the case. In fact, süra LV is the only portion of text both manuscripts are sharing, but their translation does not belong to the same textual tradition.

These groups of manuscripts: the tafăsìr and glossaries on the one hand (I+III), and the Quranic excerpts on the other (II), lead us to think that they were addressing two distinct audiences or, at least, meant for two different kinds of use. In the first case, the complete tafâsir would have been prepared for a more specialized public, entrusted with the task of explaining the Quranic text in concise form or of knowing it in more detail in order to be able to explain it afterwards before an audience. In the second case, the excerpts, we are dealing with a lighter kind of text: the copy of the Qur'ān is not complete, it only contains a selection of suras and their translation. Even if it contains elements which suggest that the translator was aware of the exegesis, it does not include commentaries as extensive as those which we found in the first group of manuscripts. The use of such copies would have been less erudite, probably also more frequent (maybe for daily prayers), without any need for more complex explanations of the Qur'ân. Although the number of copies of one or another type of translation which have been preserved from the Almonacid de la Sierra trove does not give a sound clue (four manuscripts with a tafsir translation against four translations of the selection which I call the 'Morisco Qur'ān'), the Arabic manuscripts provide us with an answer: we do not have any Arabic copy of a tafsir from the Mudejar or Morisco period among the codices found in Almonacid, whereas twelve copies of extracts of the Qur'ân in Arabic have survived. This leads us to suggest that the use of excerpts was more common and probably more necessary than that 


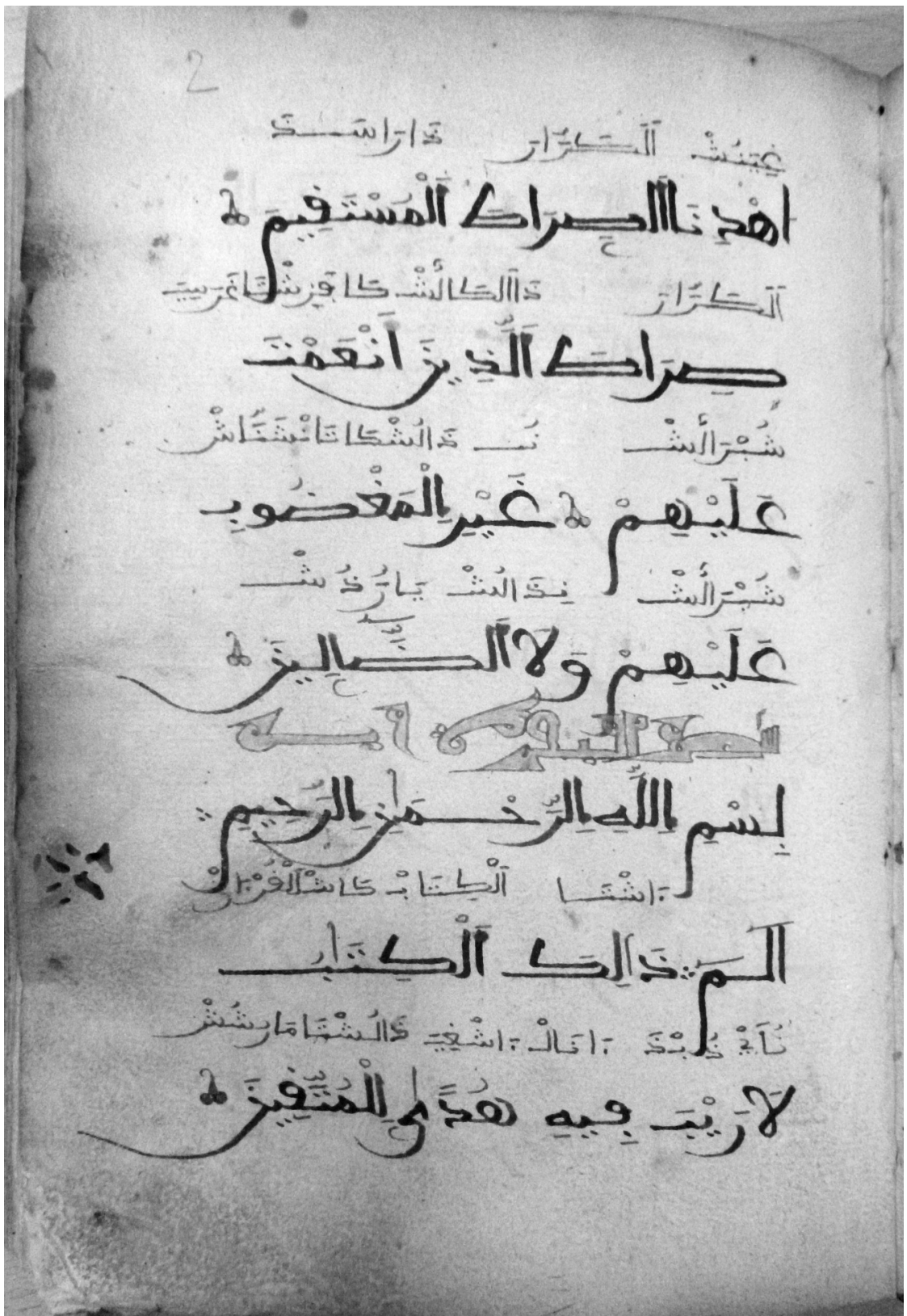

Fig. 6. RESC/25, 2r.

CCSIC, Centro de Ciencias Humanas y Sociales, Biblioteca Tomás Navarro Tomás Al-Qantara XXXV 2, 2014, pp. 493-525 ISSN 0211-3589 doi: 10.3989/alqantara.2014.017 


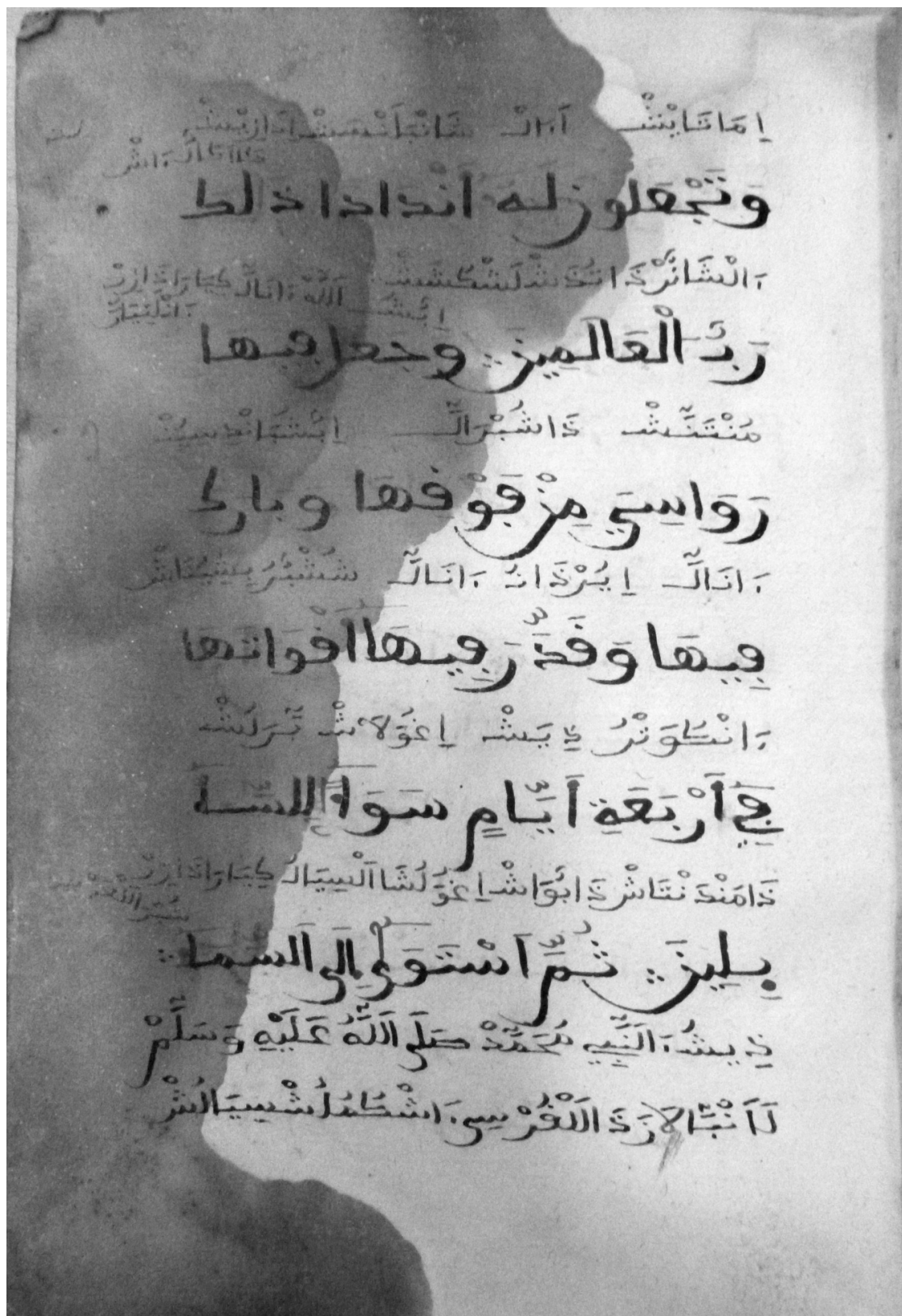

Fig. 7. RESC/18, 3r

CCSIC, Centro de Ciencias Humanas y Sociales, Biblioteca Tomás Navarro Tomás Al-Qantara XXXV 2, 2014, pp. 493-525 ISSN 0211-3589 doi: 10.3989/alqantara.2014.017 
of exegetical commentaries (without forgetting that there is no evidence of Mudejar or Morisco tafăsìr in Arabic only outside this collection either).

The fact that such a diversity of Quranic manuscripts, with a variety of uses attached to them, are found together in the same collection, as is the case with the Almonacid trove, is of great interest as it implies a high level of 'consumption' and, as a consequence, the necessity for the Muslim inhabitants of this area to have this material at hand. The intrinsic value of these translations increases when we take into account that their production is not the result of chance; quite the contrary, these copies stem from the work carried out in an organized form by a group of skilled copyists who were transcribing the text from common exemplars, who were working together to such a degree that they could probably 'line produce' in order to meet the demand for this kind of material.

When looking at the titles of the süras, it becomes clear that the ornamental script of manuscripts RESC/18, RESC/25, RESC/39E, RESC/47, RESC/51 and RESC 58B might have been drawn by the same hand -or at least prepared in the same workshop (fig. 8). This is neither the case with $\mathrm{RESC} / 40$ - only once it has an ornate sura title- nor with RESC/3.1 or $\mathrm{RESC} / 52.1$. This being said, the hand responsible for the titles is a common thread running through this collection of Quranic copies. This fact, alongside the various links which I have been showing between the manuscripts, suggests that these copies were transcribed during a comparatively short span of time, which underscores the importance of this kind of evidence in this moment. What was the rationale behind this? It could have been a production meant for internal consumption, but this seems hardly the case since Almonacid de la Sierra was certainly an important Muslim settlement in Aragon at that time, but according to some sources from the beginning of the $17^{\text {th }}$ century it only had about 1.600 inhabitants. ${ }^{45}$ It could have been a production centre of copies meant to be sold to neighbouring communities in which the expertise required for the transcription of the texts they needed was lacking.

\footnotetext{
${ }^{45}$ Almonacid de la Sierra witnessed an impressive growth of the number of its inhabitants during the $16^{\text {th }}$ century. In 1495,88 households -equivalent to about 450 people-apparently all Mudejar families. In 1609, 324 Morisco families were living in the town. "La expatriación, realizada en 1610 (perteneciendo la localidad al conde de Aranda), afectó a una población de 319 casas, lo que equivale a unas 1.600 personas, quedando la población reducida a 50 fuegos, $c a$. 250 personas" (Montaner, "El depósito de Almonacid y la producción de la literatura aljamiada. En torno al ms. misceláneo XIII," p. 119, fn. 1; see also Ansón Calvo, "Almonacid de la Sierra: un pueblo de moriscos en la encrucijada de la expulsión,” pp. 303-312).
} 


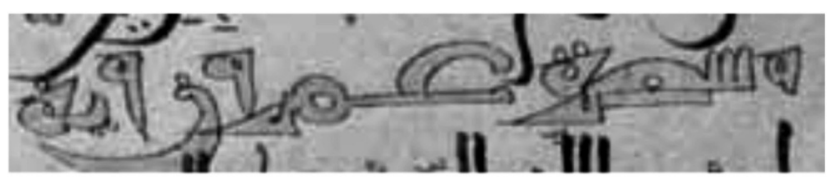

RESC/25

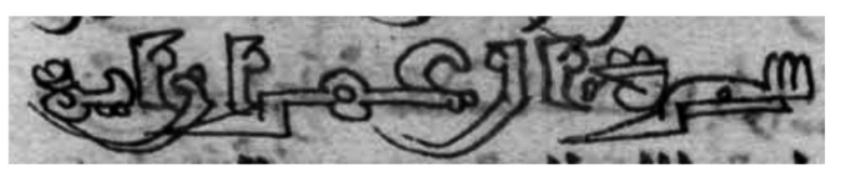

RESC/39E

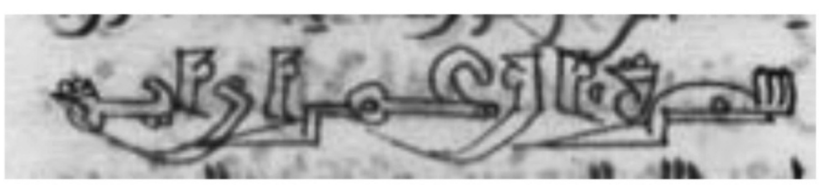

RESC/58B

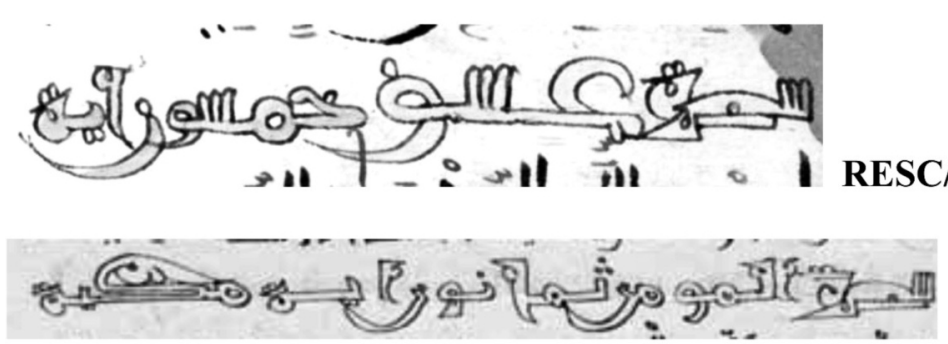

RESC/51

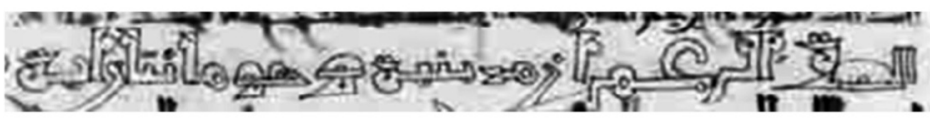

RESC/47

Fig. 8. Sūra headings.

On the basis of the results of this analysis which combined codicological and textual approaches to the manuscripts of the Almonacid de la Sierra collection, I suggest to take into account the following items which I think were not adequately considered in the schema published by LópezMorillas (fig. 9) although she was well aware of the limits of this kind of visual presentations: ${ }^{46}$

46 "Todos los puntos de coincidencia entre versiones no se pueden representar en solo dos dimensiones" (López-Morillas, Corán de Toledo, p. 80). 


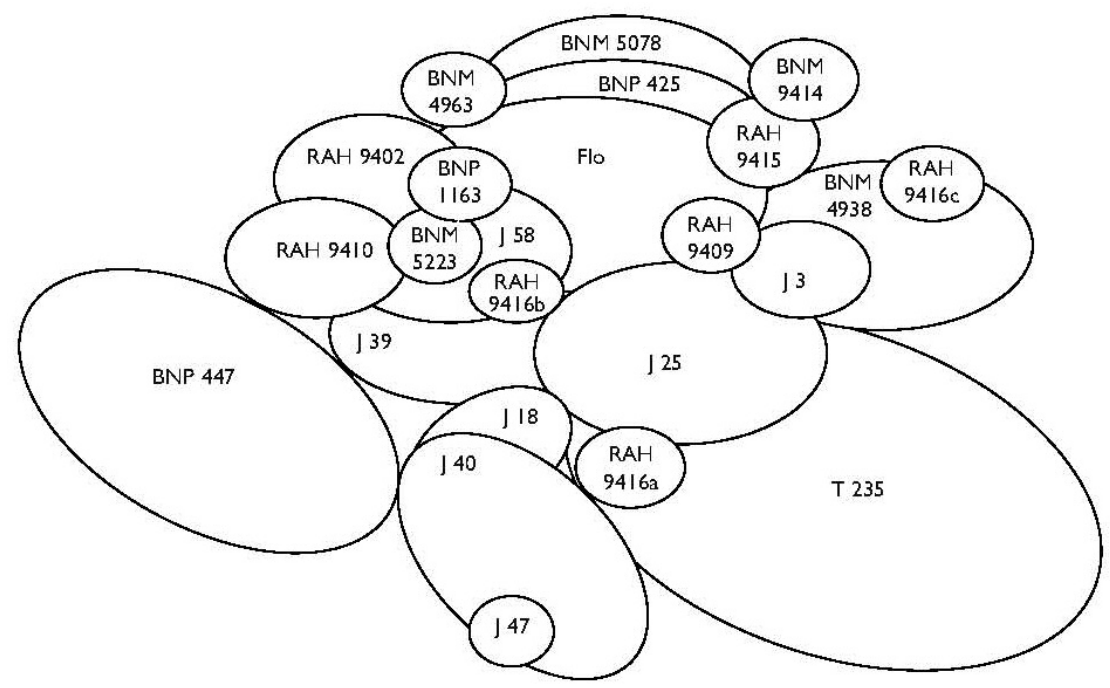

Fig. 9. Consuelo López-Morillas, "Relaciones entre todas las versiones coránicas." ${ }^{47}$

a) The nature of the texts. In a representation like this, it is not possible to determine the nature of the texts, since there is no distinction in the schema between parts of the Qur'ān, selections and glossaries. This distinction is important when discussing the hypotheses about the use of the Qur'ān in these Morisco communities. ${ }^{48}$ There is no reason to maintain, as Vernet and his followers did, that "los manuscritos 25 y 18 de la EEAM cubren ensamblados desde la azora 41 hasta el final del Libro," 49 because they are of a different nature. However, ten years later, Hermosilla made a similar statement: "interesan por el momento los mss. 18 y 25 de la EEAM, que cubren el texto coránico desde la azora 41 hasta el fin del Libro con muy escasas lagunas." ${ }^{50}$ We should have to take into account the various possible uses of each copy and the training of their readers and reciters in order to reach the conclusion that we are dealing with "un

${ }^{47}$ I would like to thank Consuelo López-Morillas and Álvaro Díaz-Huici, director of Trea publishing house, for their kind permission to reproduce in this paper the schema published in Corán de Toledo, p. 80. It exhibits some changes with respect to a former version published by the same author a few years ago in López-Morillas, "The Genealogy of the Spanish Qur'ān."

${ }^{48}$ See Martínez-de-Castilla, "Qur'ānic Manuscripts from Late Muslim Spain."

${ }^{49}$ Vernet and López-Lillo, “Un manuscrito morisco del Corán,” p. 186.

${ }^{50}$ Hermosilla, "Dos glosarios," p. 118. 
compendio abreviado, ora uno o dos cuartos del texto total, ora versos sueltos." $" 51$

b) The material aspect. It seems important to identify whether the volume circulated in an isolated way or with other contents; and whether it is complete or not. If it is not the case, one would have to decide whether its fragmentary state is the result of: a) later losses of folios; b) the decision by the scribe to copy the text in this way; or c) his own inability to complete the transcription. According to the selection of the text-and we mean here purposely made selections, not the result of later losses-, of the size and the quality of the copy, we have to deduce and to figure out various ways of transmission since it is impossible to analyze them from a single point of view as it has been done until now. Judging from the material which has been preserved, for instance, manuscripts RESC/39E and RESC/58B.1 are apparently two twin copies of Qur'ān selections which were made by the same copyist, but with only a few quires surviving from each volume. However, we can deduce from the evidence available to us that the two copies were identical in their origins, which should be rendered on the schema in a different way: closer (or even, superposed), but in no way, so apart.

c) Textual aspect. When two manuscripts transmit the same contents, it is necessary to check whether they belong to the same textual tradition or not. On another hand, it is very difficult to compare manuscripts which do not transmit the same contents. In such a situation, we have to turn back to the codicological analysis. Manuscripts RESC/47 and RESC/51 are very close both aesthetically and chronologically, but we know that they are not part of the same set (because of the differences already indicated). However, they share some material features that are sufficient to suggest that they could have been copied from a common original. In any case, they have different things in common that are not taken into account in López-Morillas' schema. Actually, RESC/51 does not appear in there, probably by inadvertence, since it was included in a schema published earlier, ${ }^{52}$ but clearly separated from RESC/47. And on the preceding page of her Corán de Toledo, RESC/51 is linked with other manuscripts (specifically with T235 and RESC/3), but not with RESC/47.

${ }^{51}$ López-Morillas, Corán de Toledo, p. 12.

${ }^{52}$ López-Morillas, "The Genealogy of the Spanish Qur'ān." 
d) "Unknown manuscript." Probably due to its atypical appearance, RESC/52.1 escaped López-Morillas' attention. It is the first chapter of a miscellany with almost 700 folios from the Almonacid de la Sierra collection, which transmits in a fragmentary way a translation with extensive commentaries belonging to the same textual tradition as RESC/51. Neither RESC/52.1 nor RESC/51 appear in this schema, although the latter has been extensively used in her study of the Corán de Toledo.

I shall try for my part to offer a new stemma-like presentation based on the study of the translations of the Qur'ān from the Almonacid de la Sierra trove kept in the Tomás Navarro Tomás library (fig. 10). This presentations aims at mapping the connections between these manuscripts:

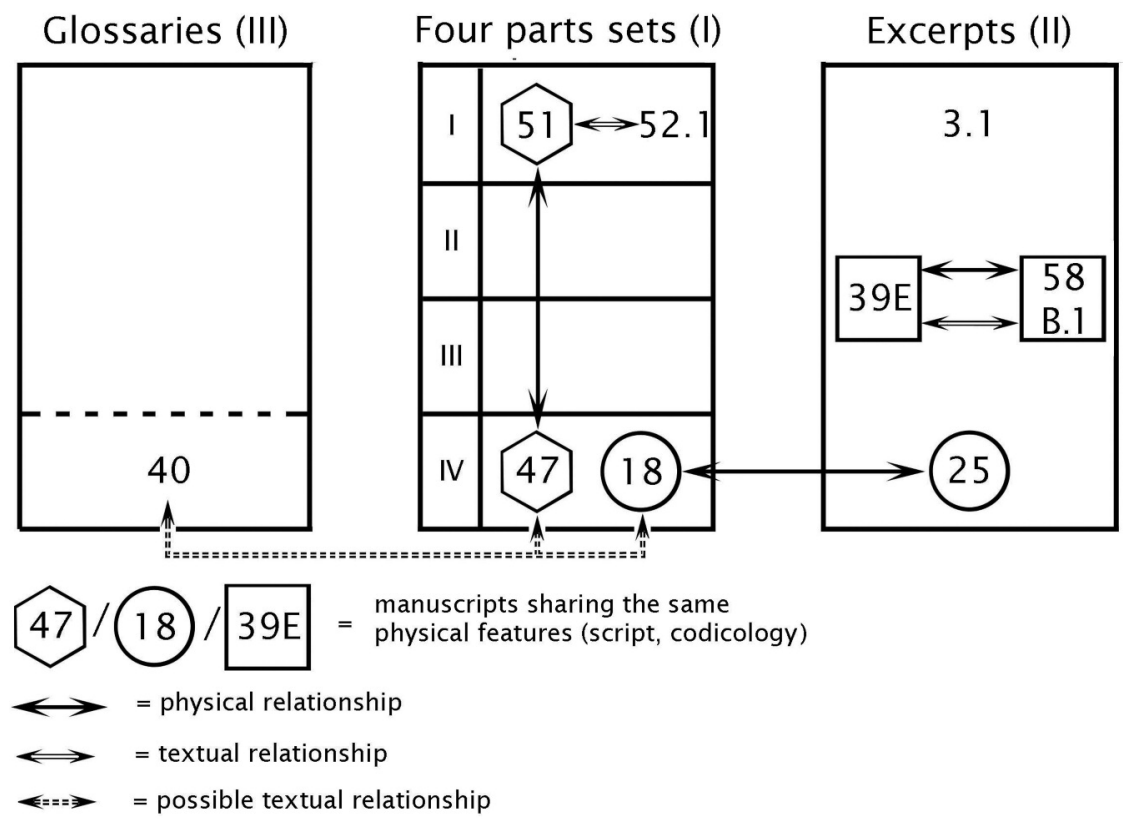

Fig. 10.

Eleven translations of the Qur'ān and of the exegetical commentaries are preserved in the Almonacid trove (four Quranic excerpts, four tafäsìr and three glossaries of the fourth part of the Qur'ān, probably for the 
tafsir). With a single exception, all these copies are closely related. As far as the production is concerned, we can identify three different copyists who were responsible for two codices each. Two of them (RESC/18 and $\mathrm{RESC} / 25$, and RESC/39E and RESC/58B.1) kept the same kind of paper, the same size and the same number of lines. But, whereas RESC/39E and RESC/58B.1 contain two witnesses of the same textual tradition, RESC/18 and RESC/25 are two different "products": respectively a translation of the tafsir of the fourth part and the "Morisco Qur'ān" (excerpts). We have therefore few common textual elements on which we could base a conclusion about a possible link between these two codices. As for the manuscripts RESC/51 and REC/47, respectively translations of the tafsir of the first and fourth parts of the Qur'ān, they seem to have been produced by the same copyist as they exhibit the same variety of script and layout; however, we cannot state that they once belonged to the same set on codicological or textual grounds.

The manuscripts RESC/39E and RESC/58B.1 ("Morisco Qur'ān") on the one hand and RESC/51 and RESC/52.1 (tafsir of the fourth part of the Qur'ān) on the other exhibit respectively passages from the same textual tradition. And it seems that the three glossaries bound together in RESC/40 (but representing two different codicological units) are closely related to the tafsir found in RESC/18 and RESC/47. One has however to be very careful with such a statement since the typology of RESC/40 as well as the reduced number of common passages in RESC/18 and $\mathrm{RESC} / 47$ are insufficient to ground firmly a conclusion. As we have seen, we are dealing with texts in a fragmentary state and belonging to various genres. This situation does not always allow us to carry out the thorough comparison which would enable us to identify the textual families to which each text belongs (although there are codicological elements that link these codices).

$$
* * *
$$

On the basis of the study of this large group of Quranic copies hidden in the same place in a small Aragonese town by the beginning of the $17^{\text {th }}$ century and taking into account all the factors involved in this case, I would like to offer here a few fresh views:

1. In spite of the dogma of inimitability of the Qur'ān by Muslim orthodoxy, the text of the Revelation has been translated into vernacular languages from early times, as it appears from al-Zamakhsharì's tafsir written 
by the middle of the $12^{\text {th }}$ century ${ }_{.}^{53} A b \bar{u}$ Hanifa, as early as the $8^{\text {th }}$ century, supported the idea that it was possible to recite the Qur'ān in another language than Arabic. ${ }^{54}$ In the same way as other non-Arabic speaking Muslim communities did, the Moriscos were transcribing translations of the Qur'ān and translated commentaries of the Sacred text because their knowledge of the Arabic language was weak, and they needed to understand properly the Qur'ān.

2. The presence of these copies in the Almonacid collection implies a double paradox: they are not only translations of the Quranic text into a vernacular language, but also copies and/or translations developped during the Morisco period, in other words, produced within crypto-Muslim communities. As I pointed out before, no Muslim was theoretically living any longer in the Iberian Peninsula after the decrees of forced conversion from the beginning of the $16^{\text {th }}$ century. However, many Moriscos did not convert to Christianity, and some of them kept providing their communities with the knowledge and understanding of the Qur'ann through the copy of the Sacred text itself and of its commented translations into vernacular language in Arabic script, although the use of the Arabic was also strictly prohibited by Christian authorities.

3. Some of the "mistakes" found in the translations could in a few cases be the result of local dialects. ${ }^{55}$ However, the knowledge of Arabic by the Morisco copyists was not very deep as a whole, but this did not prevent them from trying to transmit their religious literature in bilingual versions, quite the contrary. Thanks to the Almonacid discovery, we know that in this area skilled copyists were working systematically, either within a team or alone. In various circumstances, they were following the same models, those which were actually at hand, using the same materials (papers, inks), the same methods (layouts, scripts, etc.), and textual models, probably according to the place where they had learnt their trade and to the site where they were working. Unfortunately, we do not have for the moment enough

53 “'From al-Zamakhsharî's (d. 538/1144) exegesis of the Qur'ān, it becomes clear that he not only sanctioned the translation of the Qur'ān from the Arabic, but also that such translations actually existed." Bobzin, "Translations of the Qur'ān," p. 341a.

54 "Abū Hanifa [...] did permit translation of the Qur'ān for those who did not know Arabic well and although this position was not universally accepted, a large number of Persian translations of the Qur'ān exist from both the medieval and modern periods" (Lewis, "Persian Literature and the Qur'ān," p. 58b). See also Zadeh, The Vernacular Qur'an. Translation and the Rise of Persian Exegesis.

${ }^{55}$ Hermosilla, "Dos glosarios," p. 128. 
evidence as to trace the provenience of the various copies of the Qur'ann, with or without translation, which have come down to us from the Morisco period but were not part of the Almonacid de la Sierra trove.

4. The translation of the Qur'ān is very far from the word-for-word which the Toledo Qur'ân copyist announced in the copy mentioned at the beginning of the present study. This kind of translation is widespread in the contemporaneous Ottoman or Persian worlds, but the translations produced within Morisco context can be seen as more 'modern', being more easily understandable by the audience.

5. The help of the tafsir is crucial when one aims at producing one of those more directly comprehensible translations. Thanks to the texts which have been preserved, we can state that the Moriscos had a fairly good knowledge of the earlier tafāsìr and integrated them in a more or less extensive way into their translations. This was actually a fundamental part of the process since "Quranic exegesis represents a major branch of Islamic learning and is an essential tool of religious education." ${ }^{16}$ No earlier copies of Arabic or translated tafsir works in the Almonacid collection have been preserved, which can only be explained by the disappearance of such copies. The internal relationship between the four partial tafäsir which I have analysed and the glossaries suggest actually that a significant number of copies were circulating throughout Aragon and probably throughout the other Spanish kingdoms with Muslim communities, although only a tiny part has come down to us. However, the lack of more detailed research into this matter prevents us from knowing whether the $16^{\text {th }}$ century Morisco scribes were only transcribing translations which had been produced at an earlier date or were actively engaged in a translation activity from Arabic originals. If the second option were proved true, it would entail a revision of the commonly accepted view about the level of knowledge of Arabic in the Peninsula in the $16^{\text {th }}$ century ${ }^{57}$.

Everything indicates that Almonacid de la Sierra was an important centre of manuscript production during the Morisco period, in spite of the small size of the city -which numbered about 1.600 inhabitants at the beginning of the $17^{\text {th }}$ century. As far as the Quranic text is concerned, com-

${ }^{56}$ Ridell, "Earliest Quranic Exegetical Activity in the Malay-Speaking States," p. 109.

${ }^{57}$ Research over the past few years have been throwing light on the possible use of Arabic in the Aragonese area; see, for instance, Ferrando, “¿Un céjel andalusí-aragonés del siglo XVI?", or Ferrando "Andalusi Arabic in Post-Islamic North of Spain: the Language of Aragon's Mudejars and Moriscos." 
plete copies of the text divided into four parts were found next to selections of passages or to exegetical commentaries. Finding so many manuscripts written on the same kind of paper, transcribed by the same copyists, eventually from the same originals, and decorated by the same craftsmen, implies that they were produced over a comparatively short period of time; they could probably 'line produce' in order to meet the demand for this kind of material. If we take into account the production of so large a number of copies for so small a community over a short time span, we can conclude that the copyists in Almonacid were answering the demand from the local Morisco community as well as the needs of neighbouring areas where expertise in manuscript production and/or the materials necessary for it were lacking.

\section{Bibliography}

Ansón Calvo, M. ${ }^{\mathrm{a}}$ Carmen, "Almonacid de la Sierra: un pueblo de moriscos en la encrucijada de la expulsión," in Destierros aragoneses I. Judios y moriscos, Saragossa, Institución Fernando el Católico, 1988, pp. 303-312.

Bobzin, Hartmut, "Translations of the Qur'ān," in Encyclopaedia of the Qur'ān V, Leiden, Brill, 2004.

Déroche, François, Catalogue des manuscrits arabes II. Manuscrits musulmans, t. I, 2, Paris, Bibliothèque Nationale, 1985.

Digital Publication of the "Piccard" Collection of Watermarks, $<$ http://www.landesarchiv-bw.de/web/44577>, [Last visit on April, 2014.]

Fournel-Guérin, Jacqueline, "Le livre et la civilisation écrite dans la communauté morisque aragonaise (1540-1620)," Mélanges de la Casa de Velázquez, 15 (1979), pp. 241-259.

Ferrando, Ignacio, “¿Un céjel andalusí-aragonés del siglo XVI?”, Estudios de dialecto andalusí, 1 (1996), pp. 177-195.

Ferrando, Ignacio, "Andalusi Arabic in Post-Islamic Noth of Spain: the language of Aragon's Mudejars and Moriscos", in Manwell Mifsud (ed.), Proceedings of the Third International Conference of the Association International de Dialectologie Arabe, Malta, Salesian Press, 2000, pp. 195-200.

Galmés de Fuentes, Álvaro, Los manuscritos aljamiado-moriscos de la Biblioteca de la Real Academia de la Historia (legado Pascual de Gayangos), Madrid, Real Academia de la Historia, 1998.

Guillén Robles, Francisco, Catálogo de los manuscritos árabes existentes en la Biblioteca Nacional de Madrid, Madrid, Imprenta y Fundición de Manuel Tello, 1889. 
Hermosilla Llisterri, María José, "Corán 22, 52 en el tafsīr de Yahyà b. Salām," Al-Qantara, 12 (1991), pp. 271-272.

Hermosilla Llisterri, María José, "Dos glosarios de Corán aljamiado," Anuario de Filología, 9 (1983), pp. 117-149.

Hermosilla Llisterri, María José, "Una versión aljamiada del Corán 58, 1-3," AlQanțara, 4 (1983), pp. 423-427.

Hermosilla Llisterri, María José, “Una versión aljamiada de Corán 89, 6-8. Sobre Iram, la de las columnas," Al-Qantara, 5 (1984), pp. 33-62.

Lewis, Franklin, "Persian Literature and the Qur'ān," Encyclopaedia of the Qur'ān IV, Leiden, Brill, 2004.

López-Morillas, Consuelo, Corán de Toledo. Ed. y estudio del manuscrito 235 de la Biblioteca de Castilla-La Mancha, Gijón, Trea, 2011.

López-Morillas, Consuelo, "El Corán romanceado: la traducción contenida en el manuscrito T235," Sharq al-Andalus, 16-17 (1999-2002 [2004]) [=Homenaje a L. P. Harvey], pp. 263-284.

López-Morillas, Consuelo, "La autoría del manuscrito coránico morisco T235," in William Mejías-López (ed.), Morada de la palabra: homenaje a Luce y Mercedes López-Baralt, vol. I, San Juan, Universidad de Puerto Rico, 2002, pp. 980-988.

López-Morillas, Consuelo, "Lost and Found? Yça of Segovia and the Qur'ān Among the Mudejars and Moriscos," Journal of Islamic Studies, 10 (1999), pp. 277-292.

López-Morillas, Consuelo, “The Genealogy of the Spanish Qur'ān,” Journal of Islamic Studies, 17 (2006), pp. 255-294.

López-Morillas, Consuelo, The Qur'ān in Sixteenth-Century Spain: Six Morisco Versions of Sürat al-Nāzi 'āt, London, Tamesis, 1982.

López-Morillas, Consuelo, “"Trilingual' Marginal Notes (Arabic, Aljamiado and Spanish) in a Morisco Manuscript from Toledo," Journal of the American Oriental Society, 103 (1983), pp. 495-504.

Losada, Teresa, Estudios sobre coranes aljamiados, Barcelona, Universidad, unpublished Ph.D., 1975.

Losada, Teresa, "Estudio sobre coranes aljamiados. Resumen de la tesis doctoral," Barcelona, Universidad, 1977.

Martínez-de-Castilla-Muñoz, Nuria, "Corán de Salónica," in Alfredo Mateos y Juan Carlos Villaverde (eds.), Memoria de los moriscos. Escritos y relatos de una diáspora cultural, Madrid, Sociedad Estatal de Conmemoraciones Culturales, 2010, p. 228.

Martínez-de-Castilla-Muñoz, Nuria, "Deux corans aljamiados de Salonique," Bulletin de la Fondation Max Van Berchem, 23 (2009), pp. 4-5.

Martínez-de-Castilla-Muñoz, Nuria, “'Hacer libros no tiene fin'. Los moriscos y su patrimonio manuscrito," en El texto infinito. Tradición y reescritura en la Edad Media y el Renacimiento, Salamanca, Publicaciones del Semyr, 2014, pp. 1749-758. 
Martínez-de-Castilla-Muñoz, Nuria, Les manuscrits mudejars et morisques en France, Roma, Istituto per l'Oriente C. A. Nallino-CNRS (under press).

Martínez-de-Castilla-Muñoz, Nuria, "Manuscritos musulmanes y facticios del Aragón del siglo XVI," in Mostafa Ammadi, Francisco Vidal-Castro y María Jesús Viguera Molins (eds.), Manuscritos para comunicar culturas, Casablanca, Bouregreg, 2012, pp. 141-150.

Martínez-de-Castilla-Muñoz, Nuria, "Qur'ānic Manuscripts from Late Muslim Spain. The Collection of Almonacid de la Sierra," Journal of Quranic Studies, 16, 2 (2014), pp. 88-139.

Montaner, Alberto, "El auge de la literatura aljamiada en Aragón," in José M. ${ }^{a}$ Enguita (ed.), Actas del II curso sobre lengua y literatura en Aragón (Siglos de Oro), Saragossa, Institución "Fernando el Católico," 1993, pp. 31-61.

Montaner, Alberto, "El depósito de Almonacid y la producción de la literatura aljamiada. En torno al ms. misceláneo XIII," Archivo de Filología Aragonesa, 41 (1988), pp. 119-152.

Ribera, Julián and Asín, Miguel (dirs.), Manuscritos árabes y aljamiados de la Biblioteca de la Junta, Madrid, Junta para Ampliación de Estudios e Investigaciones Científicas, 1912.

Ridell, Peter, "Earliest Quranic Exegetical Activity in the Malay-Speaking States," Archipel, 38 (1989), pp. 107-124.

Robles Salgado, Sergio (coord.), Filigranas en la provincia de Zaragoza, Saragossa, Imprenta Provincial, 2002.

Robles Salgado, Sergio (coord.), Índice de filigranas en la provincia de Zaragoza II, Saragossa, Diputación, s. a.

Valls i Subirà, Oriol, La historia del papel en España, Madrid, Empresa Nacional de Celulosas, 1978-1980, 3 vol.

Vernet, Juan and López Lillo, Catalina, "Un manuscrito morisco del Corán," Real Academia de Buenas Letras de Barcelona, 35 (1973-1974), pp. 185-255.

Vernet, Juan and Moraleda, Luisa, "Un Alcorán fragmentario en aljamiado," Real Academia de Buenas Letras de Barcelona, 33 (1969-1970), pp. 43-75.

Wiegers, Gerard, Islamic Literature in Spanish and Aljamiado. Yça de Segovia (fl. 1450), His Antecedents and Successors, Leiden, Brill, 1994.

Zadeh, Travis, The Vernacular Qur'an. Translation and the rise of Persian exegesis, Oxford, Oxford University Press-The Institute of Islamic Studies, 2012.

Recibido: $21 / 03 / 2014$

Aceptado: 19/09/2014 